\title{
Activation of PPAR $\beta / \delta$ protects cardiac myocytes from oxidative stress-induced apoptosis by suppressing generation of reactive oxygen/nitrogen species and expression of matrix metalloproteinases
}

\author{
Eleftheria Barlaka ${ }^{\mathrm{a}}$, Anikó Görbe ${ }^{\mathrm{b}, \mathrm{d}}$, Renáta Gáspár ${ }^{\mathrm{b}}$, János Pálóczi ${ }^{\mathrm{b}}$, Péter Ferdinandy ${ }^{\mathrm{c}, \mathrm{d}}$, \\ Antigone Lazou ${ }^{\mathrm{a}, *}$
}

a Laboratory of Animal Physiology, School of Biology, Aristotle University of Thessaloniki, Greece

${ }^{\mathrm{b}}$ Cardiovascular Research Group, Department of Biochemistry, University of Szeged, Hungary

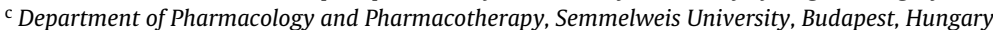

d Pharmahungary Group, Szeged, Hungary

\section{A R T I C L E I N F O}

\section{Article history:}

Received 2 November 2014

Received in revised form 15 March 2015

Accepted 15 March 2015

Available online 28 March 2015

\section{Keywords:}

Cardiac myocytes

Oxidative stress

Apoptosis

Matrix metalloproteinases

$\operatorname{PPAR} \beta / \delta$

Caspase 3

Bcl-2

Chemical compounds studied in this article: Hydrogen peroxide (PubChem CID: 784) GW0742 (PubChem CID: 9934458) GSK0660 (PubChem CID: 46233311)

\begin{abstract}
A B S T R A C T
Heart failure still remains one of the leading causes of morbidity and mortality worldwide. A major contributing factor is reactive oxygen/nitrogen species (RONS) overproduction which is associated with cardiac remodeling partly through cardiomyocyte apoptosis. Peroxisome proliferator-activated receptors (PPARs) are ligand-activated transcription factors that belong to the nuclear receptor superfamily and have been implicated in cardioprotection. However, the molecular mechanisms are largely unexplored. In this study we sought to investigate the potential beneficial effects evoked by activation of PPAR $\beta / \delta$ under the setting of oxidative stress induced by $\mathrm{H}_{2} \mathrm{O}_{2}$ in adult rat cardiac myocytes. The selective PPAR $\beta / \delta$ agonist GW0742 inhibited the $\mathrm{H}_{2} \mathrm{O}_{2}$-induced apoptosis and increased cell viability. In addition, generation of RONS was attenuated in cardiac myocytes in the presence of PPAR $\beta / \delta$ agonist. These effects were abolished in the presence of the PPAR $\beta / \delta$ antagonist indicating that the effect was through PPAR $\beta / \delta$ receptor activation. Treatment with PPAR $\beta / \delta$ agonist was also associated with attenuation of caspase- 3 and PARP cleavage, upregulation of anti-apoptotic Bcl-2 and concomitant downregulation of pro-apoptotic Bax. In addition, activation of PPAR $\beta / \delta$ inhibited the oxidative-stress-induced MMP-2 and MMP-9 mRNA upregulation. It is concluded that PPAR $\beta / \delta$ activation exerts a cytoprotective effect in adult rat cardiac myocytes subjected to oxidative stress via inhibition of oxidative stress, MMP expression, and apoptosis. Our data suggest that the novel connection between PPAR signaling and MMP down-regulation in cardiac myocytes might represent a new target for the management of oxidative stress-induced cardiac dysfunction.
\end{abstract}

@ 2015 Elsevier Ltd. All rights reserved.

\section{Introduction}

Cardiovascular diseases still remain one of the leading causes of mortality and morbidity worldwide. Over the past years, clinical and experimental studies have provided substantial evidence that oxidative stress, defined as an imbalance between free radical production and their detoxification by antioxidants, is an important contributing factor in the pathogenesis of a variety of cardiovascular diseases including ischemic heart disease and heart failure

\footnotetext{
* Corresponding author at: Laboratory of Animal Physiology, School of Biology, Aristotle University of Thessaloniki, Thessaloniki 54124, Greece.

Tel.: +30 2310998381 ; fax: +302310998269.

E-mail address: lazou@bio.auth.gr (A. Lazou).
}

$[1,2]$. Excessive generation of reactive oxygen/nitrogen species (RONS) causes cellular dysfunction, protein and lipid peroxidation, DNA damage, activation of matrix metalloproteinases (MMPs) and can lead to irreversible cell damage and cell death. The control of myocyte loss through suppression of cell death pathways represents a promising strategy to prevent cardiac diseases. Terminally differentiated adult cardiac myocytes die primarily by apoptosis or necrosis [3]. Mitochondrial damage, cytochrome c release and activation of cysteine proteases caspase 9 and 3 have been implicated in apoptotic pathways. The Bcl-2 family proteins, which contain both pro-apoptotic and anti-apoptotic members, have been recognized as important modulators of cardiac myocyte apoptosis as in other cells [4,5]. Bcl-2 family proteins act at the mitochondria either as heterodimers or as homodimers to regulate cytochrome $\mathrm{c}$ whereas the dynamic equilibrium between such 
complexes appears to determine the predisposition to apoptosis [6].

The zinc-dependent endopeptidases, matrix metalloproteinases (MMPs), which have been known for their ability to proteolyse extracellular matrix proteins, play an important role in tissue remodeling associated with various physiological and pathological processes including chronic heart failure [7]. It is now recognized that MMPs can also have non-matrix related intracellular protein targets and can regulate diverse cellular functions contributing to cardiac dysfunction, such as oxidative stress-induced cell death [8-10]. Thus, MMPs are considered to be viable drug targets in the therapy of cardiac pathologies.

Peroxisome proliferator activated receptors (PPARs) are ligand activated transcription factors that belong to the superfamily of nuclear hormone receptors and include 3 members $(\alpha, \beta / \delta, \gamma)$ with tissue specific but overlapping expression patterns. Upon activation by their natural or pharmaceutical specific ligands, PPARs regulate the expression of genes mostly involved in lipid and carbohydrate metabolism, energy production and inflammation [11]. It has been also shown that PPARs may play a role in regulating transcriptional expression of antioxidants, such as $\mathrm{Cu} / \mathrm{Zn}$-superoxide dismutase (SOD1), manganese superoxide dismutase (SOD2), and catalase $[12,13]$. Furthermore, emerging evidence indicates that activation of PPARs, in particular PPAR $\alpha$ or PPAR $\gamma$, may exert cardioprotective effects beyond their metabolic effects, decreasing infarction after I/R and preventing cardiac remodeling and failure [14-17]. However, the mechanisms underlying these protective effects are largely unexplored, and it is still a matter of debate whether cardioprotection is attributable to the modulation of cardiac energy metabolism or to antioxidative and anti-inflammatory effects of PPARs $[18,19]$. Although PPAR $\beta / \delta$ is the predominant subtype in the heart, it is the least studied member of the PPAR family. Cardiac PPAR $\beta / \delta$ deletion in mice resulted in depressed bioenergetics, cardiac hypertrophy, and congestive heart failure [20] while it has been shown that PPAR $\beta / \delta$ is essential for the adult heart to maintain mitochondrial capacity and oxidative metabolism [21].

Given the emerging role of PPAR $\beta / \delta$ in regulating mitochondrial biogenesis and metabolism, we hypothesized that PPAR $\beta / \delta$ activation may ameliorate oxidative stress-induced cardiac myocyte damage. We used the highly selective and potent PPAR $\beta / \delta$ agonist GW0742 [22] and a specific PPAR $\beta / \delta$ antagonist, GSK0660 [23] as pharmacological tools to evaluate the effects of receptor activation in $\mathrm{H}_{2} \mathrm{O}_{2}$-induced cardiac myocyte apoptosis and explore the contributing mechanisms. We demonstrate that PPAR $\beta / \delta$ activation in cardiac myocytes leads to the inhibition of RONS generation, downregulation of MMP-2 and MMP-9 gene expression and prevents apoptosis.

\section{Materials and methods}

\subsection{Animals}

Male Wistar rats weighing between 250 and $300 \mathrm{~g}$ were used. Animals received proper care in compliance with the "Guidelines for the Care and Use of Laboratory Animals" published by US National Institutes of Health (NIH publication No 85-23, revised 1996) and the "Principles of laboratory animal care" published by the Greek Government (160/1991) based on EU regulations (86/609). All surgery was performed under sodium pentobarbital anesthesia, and all efforts were made to minimize suffering.

\subsection{Isolation of adult rat cardiac myocytes and treatments}

Ventricular myocytes were isolated by cardiac retrograde aortic perfusion and collagenase treatment as described previously
[24]. Cells were finally resuspended in incubation medium, in which added $\mathrm{Ca}^{2+}$ was gradually increased to $1 \mathrm{mM}$. Preparations were considered satisfactory only if the yield of rod-shaped cells was more than 70\%. Experiments were performed 30 min after dissociation. Cardiac myocytes were either left untreated, or they were pre-treated with the PPAR $\beta / \delta$ agonist GW0742 (50 nM) (Sigma-Aldrich Chemie GmbH, Taufkirchen, Germany) for $10 \mathrm{~min}$ before exposure to $\mathrm{H}_{2} \mathrm{O}_{2}(0.1 \mathrm{mM})$. When the PPAR $\beta / \delta$ antagonist GSK0660 $(0.5 \mu \mathrm{M})$ (Tocris Bioscience, Bristol, UK) was used, it was added $10 \mathrm{~min}$ before the addition of the agonist GW0742. The concentration of $\mathrm{H}_{2} \mathrm{O}_{2}$ to induce apoptosis was chosen according to our previous studies [24-26]. The optimal concentration of PPAR $\beta / \delta$ agonist and antagonist were chosen according to preliminary experiments. Preliminary experiments also established that the concentrations of the agonist and antagonist used did not affect the viability of cardiac myocytes. The experimental protocols are summarized in Fig. 1.

\subsection{Determination of cell viability}

Cell viability was determined using the 3-(4,5-dimethylthiazol2-yl)-2,5-diphenyltetrazolium bromide (MTT) assay which assesses mitochondrial activity in living cells. Cardiac myocytes $\left(10^{5} /\right.$ sample) were either left untreated or they were pretreated with PPAR $\beta / \delta$ agonist and/or antagonist $(10 \mathrm{~min})$, followed by exposure to $\mathrm{H}_{2} \mathrm{O}_{2}$ for $3 \mathrm{~h}$. Tetrazolium bromide at a concentration $0.1 \mathrm{mg} / \mathrm{ml}$ was added $10 \mathrm{~min}$ before the end of incubation. At the end of incubation, $1 \mathrm{ml}$ of ethanol was added for $10 \mathrm{~min}$ to dissolve formazan precipitate. Absorbance was measured at $570 \mathrm{~nm}$ using a microplate autoreader. Cell viability was calculated as percentage of control OD. Negative controls were used to ensure that the drugs used for the cell treatments did not interfere on their own with the formation of formazan.

\subsection{Measurement of lactate dehydrogenase ( $L D H)$}

LDH release into the cell culture medium was used as an indicator of cell death. LDH activity was determined by spectrophotometric analysis measuring the decrease in absorbance at $340 \mathrm{~nm}$ resulting from the oxidation of NADH. At the end of treatments, cell culture medium was collected and LDH activity was measured after addition of $\mathrm{NADH}(0.17 \mathrm{mM})$ and sodium pyruvate (1 mM). LDH activity was expressed as munits/mg after determination of protein content per sample by Bradford assay.

\subsection{Evaluation of apoptosis}

Apoptosis was determined by staining cells with Annexin VFITC and propidium iodide for flow cytometric analysis (Biolegend Europe). Briefly, after treatments, cells were washed twice with cold phosphate-buffered saline and resuspended. The cells were incubated with Annexin V-FITC and propidium iodide for $15 \mathrm{~min}$ in the dark. The samples were then subjected to flow cytometric analysis to detect the percentage of apoptotic (FITC-stained) and necrotic (PI-stained) cells in a given population. Fluorescence was measured on a CyFlow ML flow cytometer (Partec $\mathrm{GmbH}$, Germany). Preliminary experiments established that the agonist GW0742 or the antagonist GSK0660 used for the treatment of cells did not interfere on their own in the measurement of fluorescence.

\subsection{RONS detection}

Intracellular RONS production was evaluated using the 5(and-6)-chloromethyl-2',7'-dichlorodihydrofluorescein diacetate (CM- $\mathrm{H}_{2}$ DCFDA) (Sigma-Aldrich Chemie GmbH, Taufkirchen, 


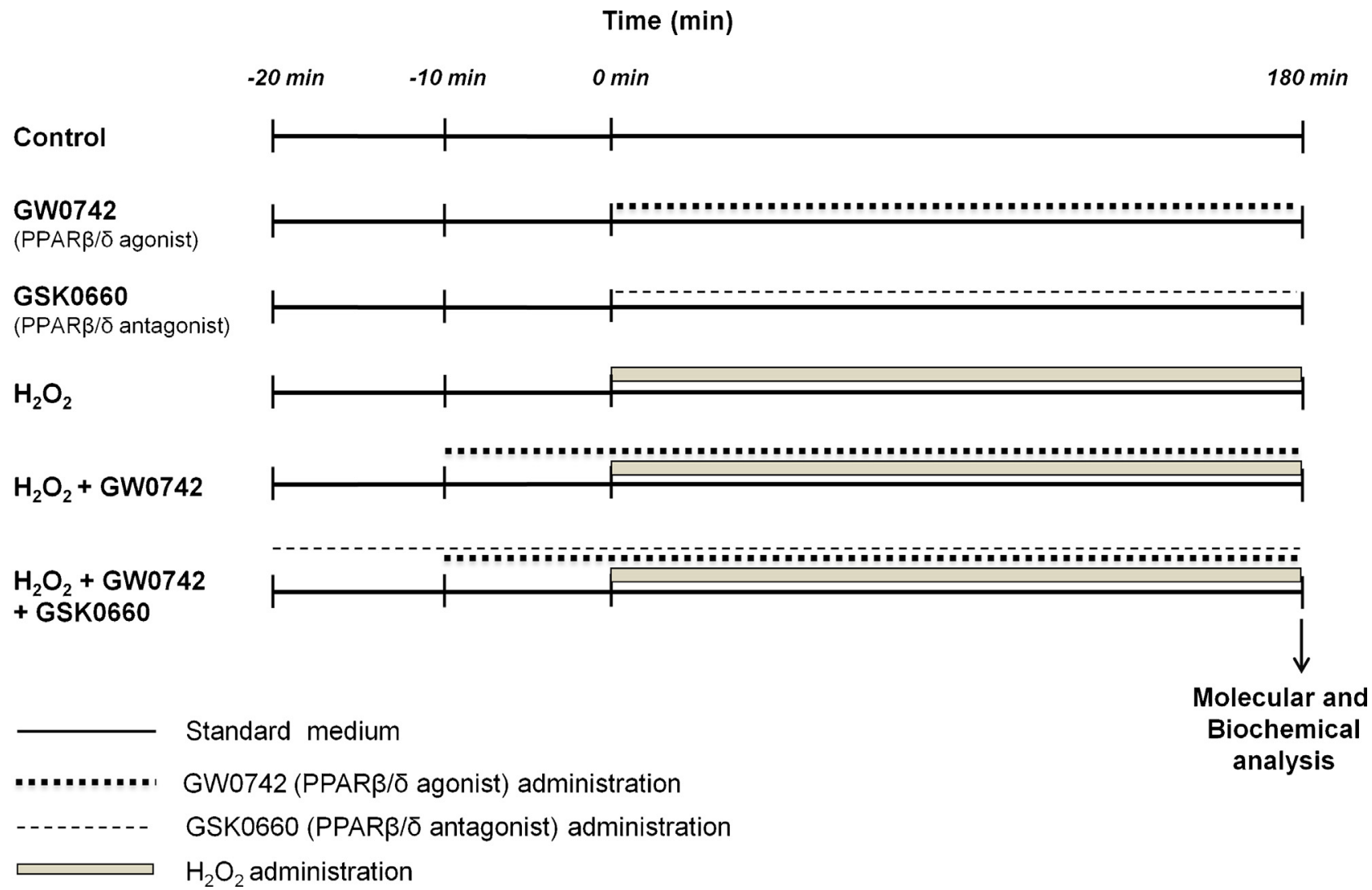

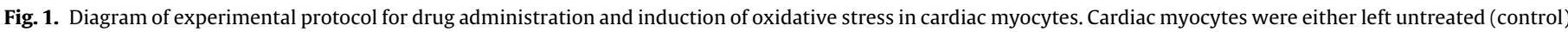

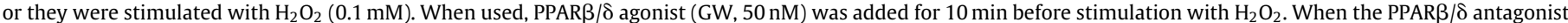
was used (GSK, $0.5 \mu \mathrm{M}$ ), it was added $10 \mathrm{~min}$ before the addition of PPAR $\beta / \delta$ agonist GW0742.

Germany). In brief, cardiac myocytes were loaded with CM$\mathrm{H}_{2}$ DCFDA $(5 \mu \mathrm{g} / \mathrm{ml})$ and then, they were either left untreated or they were pretreated with the PPAR $\beta / \delta$ agonist GW0742 for $10 \mathrm{~min}$ and/or the antagonist GSK0660 $(0.5 \mu \mathrm{M})$, in the presence or in the absence of $\mathrm{H}_{2} \mathrm{O}_{2}(0.1 \mathrm{mM})$ for $3 \mathrm{~h}$. RONS-induced fluorescence was detected by flow cytometry (CyFlow ML, Partec GmbH, Germany). Preliminary experiments established that GW0742 or GSK0660 did not interfere on their own in the measurement of fluorescence.

\subsection{Isolation of RNA and quantitative PCR ( $q P C R)$}

Total RNA was extracted using TRI Reagent (Molecular Research Center, Cincinnati, OH, USA) according to the manufacturer's instructions. The RNA was resuspended in $0.1 \%(\mathrm{v} / \mathrm{v})$ diethylpyrocarbamate-treated water and its concentration was determined by absorbance at $260 \mathrm{~nm}$. The integrity of isolated RNA was verified on a $1 \%$ agarose gel. For cDNA synthesis, $1 \mu \mathrm{g}$ of total RNA was denatured in the presence of random 9-mers (Takara, Japan) in a reaction volume of $10 \mu \mathrm{l}$ at $65^{\circ} \mathrm{C}$ for $5 \mathrm{~min}$. RNA was reverse-transcribed with PrimeScript Reverse Transcriptase enzyme (Takara, Japan), dNTP's (HyTest Ltd., Finland) and Human Placental Ribonuclease inhibitor (HT Biotechnology Ltd., Cambridge, UK). The reaction, in total volume of $20 \mu \mathrm{l}$, was carried out for $1 \mathrm{~h}$ at $37^{\circ} \mathrm{C}$, and was terminated by heat inactivation of the reverse transcriptase at $95^{\circ} \mathrm{C}$ for $5 \mathrm{~min}$. qPCR analysis was performed using a Real-Time PCR System (Applied Biosystems) with a specific set of primers for each gene (VBC Genomics). The forward and reverse primers used for gene expression were the following:

$\begin{array}{ll}\text { Catalase: } & \text { For: CCTGTG AACTGTCCCTACCG } \\ & \text { Rev: ACCCAGTCCCATGCTCTCTC } \\ \text { MMP-2: } & \text { For: TTGATGACGATGAGCTGTGG } \\ & \text { Rev: CTGCTGTATTCCCGACCATT } \\ \text { MMP-9: } & \text { For: CCGTGGTCCCCACTTACTTT } \\ & \text { Rev: CCGTGGTGCAGGACAAATAG } \\ \text { B-actin: } & \text { For: GCCCTGAGGCACTCTTCCA } \\ & \text { Rev: CGGATGTCCACGTCACACTTC }\end{array}$

Each reaction mix contained $5 \mu$ l KAPA SYBR FAST qPCR Kit (Kapa Biosystems), $0.3 \mu$ l oligonucleotides ( $10 \mathrm{pmol}$ each of forward and reverse primers) and $2 \mu \mathrm{l}$ cDNA (diluted 1:10). qPCR analysis of $\beta$-actin was performed as an endogenous control. PCR conditions were $95^{\circ} \mathrm{C}$ for $20 \mathrm{~min}$, followed by 40 cycles of $95^{\circ} \mathrm{C}$ for $3 \mathrm{~s}$ and $60^{\circ} \mathrm{C}$ for $30 \mathrm{~min}$. Following $\mathrm{qPCR}$, dissociation curve analysis was routinely performed to check for aberrant amplification products (e.g. primers-dimers). Relative changes in expression were calculated using the $2^{(-\Delta \Delta \mathrm{ct})}$ method.

\subsection{Preparation of whole cell extracts}

Cardiac myocytes were lysed at $4{ }^{\circ} \mathrm{C}$ in a buffer containing $20 \mathrm{mM} \beta$-glycerophosphate, $20 \mathrm{mM}$ HEPES pH 7.5, $50 \mathrm{mM} \mathrm{NaF}$, $2 \mathrm{mM}$ EDTA, $0.2 \mathrm{mM} \mathrm{Na}_{3} \mathrm{VO}_{4}, 10 \mathrm{mM}$ benzamidine, $5 \mathrm{mM}$ DTT, $0.3 \mathrm{mM}$ PMSF, $0.2 \mathrm{mM}$ leupeptin, $0.01 \mathrm{mM}$ E64 and 1\% (v/v) Triton X-100. Lysates were incubated on ice for $10 \mathrm{~min}$ and then centrifuged at $4{ }^{\circ} \mathrm{C}$, for $15 \mathrm{~min}$ at $10,000 \times \mathrm{g}$. Supernatants were collected, and total protein was measured using the Bradford assay (BioRad, Hercules, CA, USA).

\subsection{Immunoblotting}

Total protein extracts were boiled with $0.33 \mathrm{vol}$ of SDSpolyacrylamide gel electrophoresis sample buffer (10\% SDS $(w / v)$, 
13\% glycerol (v/v), 300 mM Tris- $\mathrm{HCl}, \mathrm{pH} 6.8,130 \mathrm{mM}$ dithiothreitol and $0.2 \%$ bromophenol blue $(\mathrm{w} / \mathrm{v})$. Proteins were separated by SDS-PAGE on $10 \%$ acrylamide, $0.275 \%(\mathrm{w} / \mathrm{v}$ ) bis-acrylamide slab gels and transferred electrophoretically onto nitrocellulose membranes $(0.45 \mu \mathrm{m})$. Nonspecific binding sites were blocked (30 min at room temperature) with $5 \%(\mathrm{w} / \mathrm{v})$ nonfat milk powder in TBST buffer [20 mM Tris- $\mathrm{HCl}$ pH 7.5, $137 \mathrm{mM} \mathrm{NaCl}, 0.1 \%$ (v/v) Tween 20]. Membranes were incubated (overnight, $4{ }^{\circ} \mathrm{C}$ ) with primary antibodies diluted in TBST buffer containing $5 \%(\mathrm{w} / \mathrm{v})$ bovine serum albumin, then washed in TBST buffer $(3 \times 5 \mathrm{~min}$, room temperature). Primary antibodies against Bcl-2 (\#2876), cleaved caspase-3 (\#8698), PARP (\#9542), $\beta$-actin (\#8457), $\alpha$-tubulin (\#2125) (Cell Signaling, Beverly, MA, USA) and Bax (sc-7480, Santa Cruz Biotechnology, Texas, USA) were used at various dilutions. Membranes were incubated (60 min, room temperature) with horseradish peroxidase (HRP) conjugated secondary antibodies $(1 / 5000)$ in TBST buffer containing $1 \%(\mathrm{w} / \mathrm{v})$ non-fat milk powder, and they were then washed in TBST buffer $(3 \times 5 \mathrm{~min}$, room temperature). Proteins were detected by enhanced chemiluminescence (Cell Signaling, Beverly, MA, USA) and quantified by scanning densitometry.

\subsection{Statistical analysis}

Data are presented as mean \pm SEM of $n$ independent experiments using different cell isolations from different animals. Statistical analyses (ANOVA with Dunnett's comparison test) were performed with significance taken as being established at $p<0.05$.

\section{Results}

\subsection{Activation of PPAR $\beta / \delta$ with the agonist GW0742 increases cell viability and attenuates $L D H$ release during exposure of cardiac myocytes to $\mathrm{H}_{2} \mathrm{O}_{2}$}

We have previously shown that $\mathrm{H}_{2} \mathrm{O}_{2}$, at concentrations higher than $0.05 \mathrm{mM}$, decreases viability and induces apoptosis in cardiac myocytes [24-26]. Consistent with these studies, exposure of cardiac myocytes to $0.1 \mathrm{mM} \mathrm{H}_{2} \mathrm{O}_{2}$ for $3 \mathrm{~h}$ decreased the viability of cardiac myocytes by almost $40 \%$ and caused an almost fourfold increase in LDH activity measured in the culture medium (Fig. 2A and B). Pre-treatment of cardiac myocytes with the PPAR $\beta / \delta$ agonist, GW0742, significantly enhanced survival while attenuated $\mathrm{LDH}$ release. In order to determine whether this is a PPAR $\beta / \delta$ mediated effect, the specific antagonist of PPAR $\beta / \delta$, GSK0660, was used. As shown in Fig. 2A, the PPAR $/ \delta$ agonist GW0742 was unable to increase cell viability in the presence of the PPAR $\beta / \delta$ antagonist GSK0660 indicating that this effect on cardiac myocyte survival is dependent of PPAR $\beta / \delta$ activation. Similarly, the antagonist abolished the protective effect of PPAR $\beta / \delta$ agonist on LDH release (Fig. 2B). Neither the agonist GW0742 nor the antagonist GSK0660 had any effect on cell survival or LDH activity when used alone.

\subsection{Activation of PPAR $\beta / \delta$ with the agonist GW0742 protects cardiac myocytes from $\mathrm{H}_{2} \mathrm{O}_{2}$-induced apoptosis}

Consistent with previous data [24-26] exposure of cardiac myocytes to $0.1 \mathrm{mM}$ of $\mathrm{H}_{2} \mathrm{O}_{2}$ resulted in almost $50 \%$ increase in the rate of apoptosis (Fig. $3 \mathrm{~A}$ ) whereas pre-treatment with the PPAR $\beta / \delta$ agonist, GW0742, significantly attenuated apoptosis. In the presence of the PPAR $\beta / \delta$ antagonist GSK0660, the PPAR $\beta / \delta$ agonist GW0742 was unable to attenuate cardiac myocyte apoptosis indicating that the protective effect of the agonist is dependent on PPAR $\beta / \delta$ activation. To corroborate further these results, caspase3 activation and poly ADP-ribose polymerase (PARP) cleavage were also evaluated under the same conditions. The activation of caspase-3, the primary executioner of cell death by proteolytic processing of pro-caspase, serves as an early marker of apoptosis in various cell types. The activation of caspases results in proteolytic cleavage of numerous substrates including PARP, a nuclear enzyme involved in DNA repair that is considered to be a hallmark of apoptosis [27]. As shown in Fig. 3B and $C$, pre-treatment of cardiac myocytes with the PPAR $\beta / \delta$ agonist GW0742 inhibited $\mathrm{H}_{2} \mathrm{O}_{2}$-induced caspase- 3 and PARP cleavage, an effect that is reversed in the presence of the PPAR $\beta / \delta$ antagonist GSK0660.

\subsection{Activation of PPAR $\beta / \delta$ with the agonist GW0742 protects cardiac myocytes from $\mathrm{H}_{2} \mathrm{O}_{2}$-induced oxidative stress}

Given the protective effect of PPAR $\beta / \delta$ activation on cardiac myocyte viability, and apoptosis, we sought to examine the potential of PPAR $\beta / \delta$ agonist GW0742 to ameliorate intracellular generation of RONS in cardiac myocytes. Cells were loaded with the fluorophore $\mathrm{CM}-\mathrm{H}_{2}$ DCFDA before treatment with $\mathrm{H}_{2} \mathrm{O}_{2}$, and/or PPAR $\beta / \delta$ agonist GW0742 and fluorescence was determined with flow cytometry. As expected, exposure of cardiac myocytes to $\mathrm{H}_{2} \mathrm{O}_{2}$ resulted in increased generation of RONS indicative of oxidative stress (Fig. 4). However, addition of the PPAR $\beta / \delta$ agonist completely abolished the increase of RONS induced by $\mathrm{H}_{2} \mathrm{O}_{2}$. The inhibitory effect of PPAR $\beta / \delta$ agonist GW0742 on intracellular RONS production was reversed when the antagonist GSK0660 was added,
A

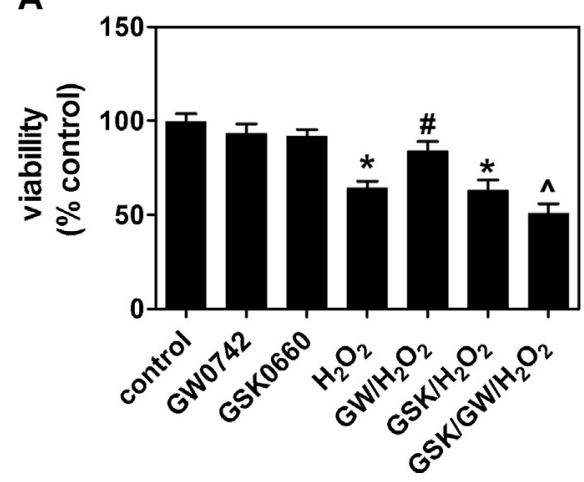

B

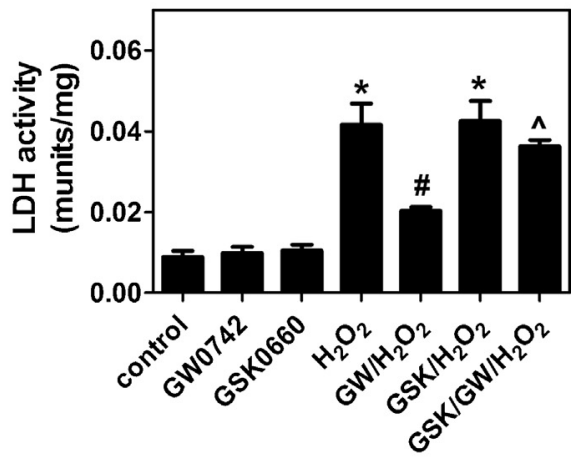

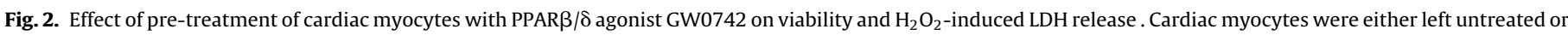

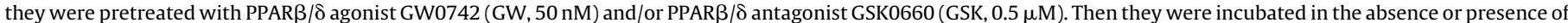

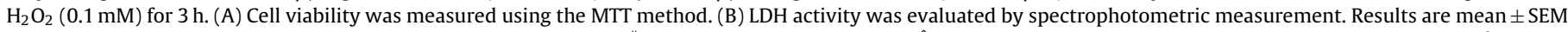

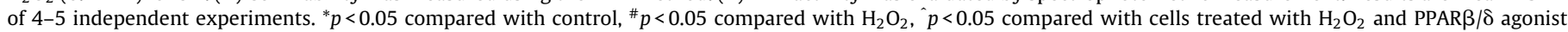
GW0742. 
A

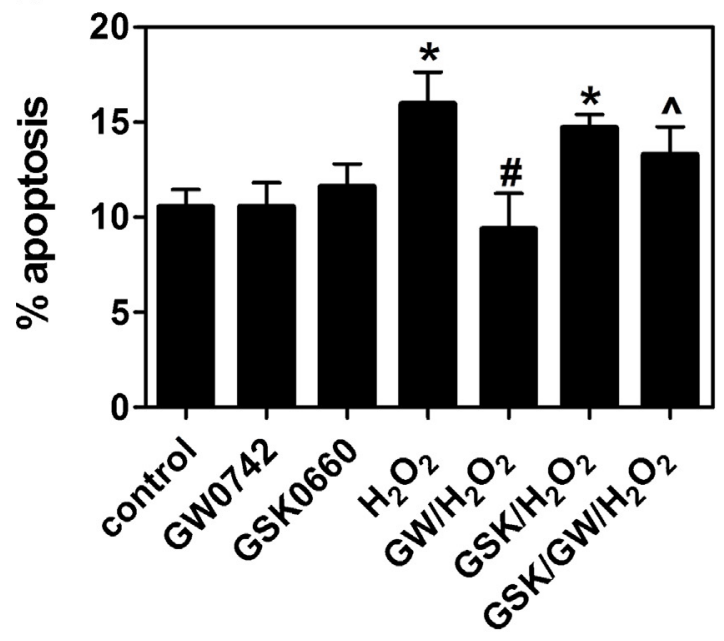

control

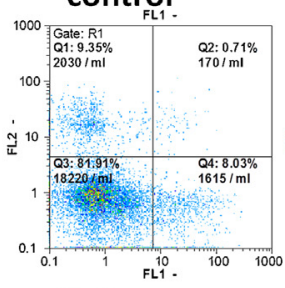

$\mathrm{H}_{2} \mathrm{O}_{2}$

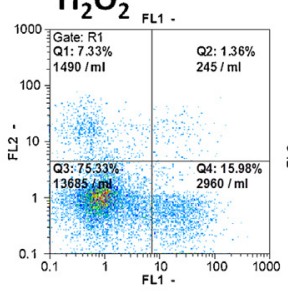

GW0742

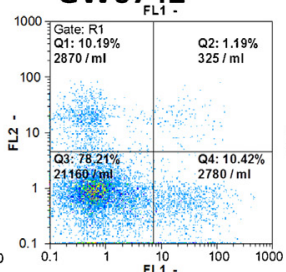

$\mathrm{GW} / \mathrm{FL}_{2} \mathrm{O}_{2}$

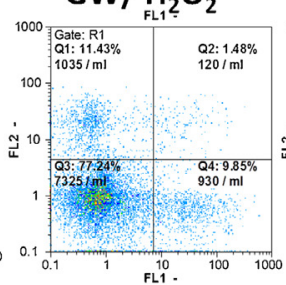

$\mathrm{GSK} / \mathrm{GW} / \mathrm{H}_{2} \mathrm{O}_{2}$

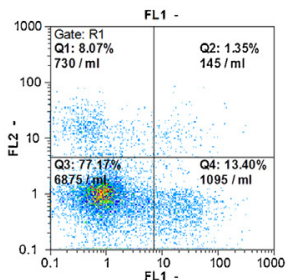

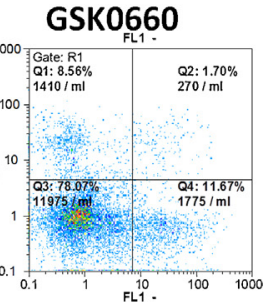

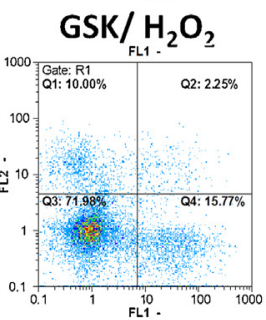

B

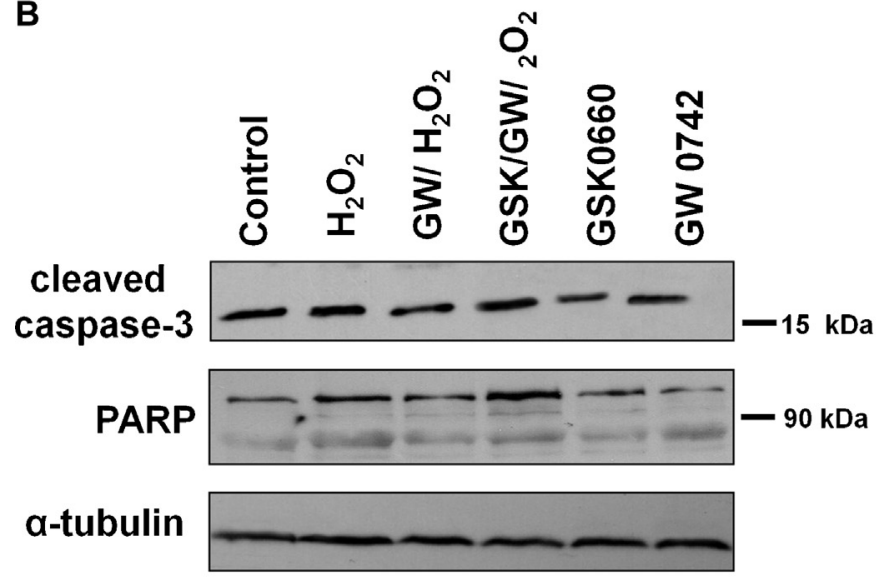

C

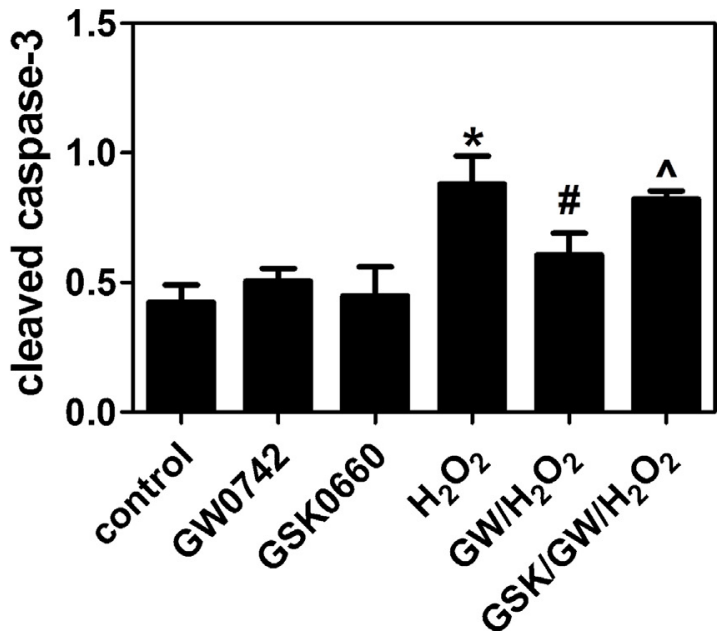

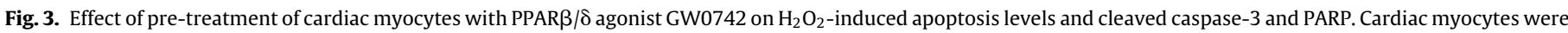

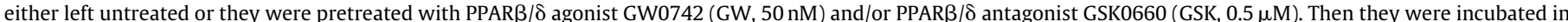

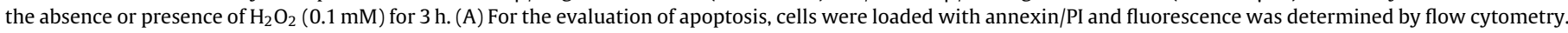

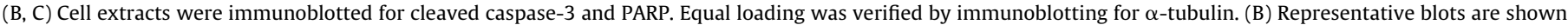

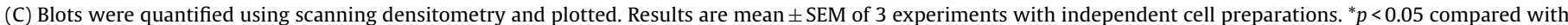
control, ${ }^{*} p<0.05$ compared with cells treated only with $\mathrm{H}_{2} \mathrm{O}_{2}, \hat{p}<0.05$ compared with cells treated with $\mathrm{H}_{2} \mathrm{O}_{2}$ and PPAR $\beta / \delta$ agonist GW0742.

verifying that this effect is mediated through PPAR $\beta / \delta$ activation. Furthermore, the mRNA levels of catalase, which is known to be a PPAR $\beta / \delta$ target gene [28], were also measured under the same conditions (Fig. 5). Catalase was up-regulated in cardiac myocytes that were pre-treated with PPAR $\beta / \delta$ agonist GW0742 as compared with the non-treated cells whereas addition of the PPAR $\beta / \delta$ antagonist abolished this effect indicating the activation of the receptor. Taken together these experiments point toward the antioxidant role of PPAR $\beta / \delta$ activation.

\subsection{PPAR $\beta / \delta$ activation modulates Bcl-2 family protein expression during cardiac myocyte oxidative stress}

We next determined whether the protective effect of PPAR $\beta / \delta$ activation can be attributable to upregulation of $\mathrm{Bcl}-2$ protein. The Bcl-2 family proteins are key components of the apoptotic process in cardiac myocytes and the ratio Bcl-2/Bax is widely used as a marker of apoptosis [24,25]. We, thus, determined the protein levels of the anti-apoptotic Bcl-2 and the pro-apoptotic Bax. 

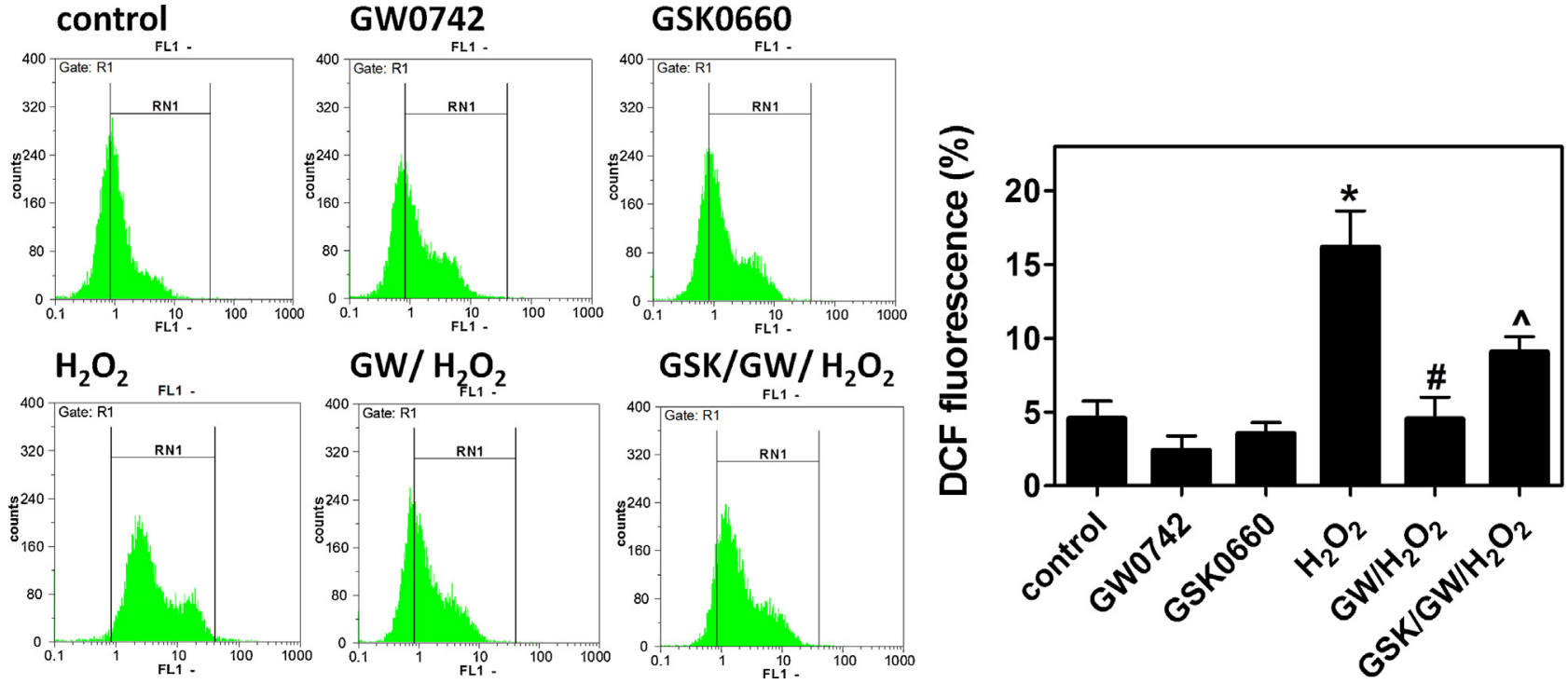

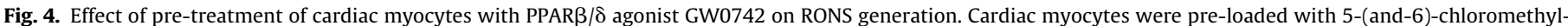

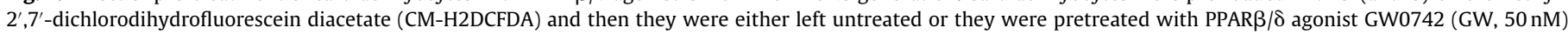

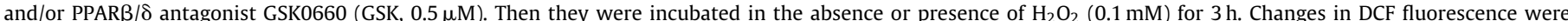

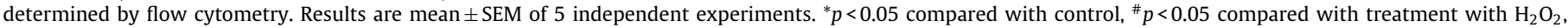
$\hat{p}<0.05$ compared with cells treated with $\mathrm{H}_{2} \mathrm{O}_{2}$ and PPAR $\beta / \delta$ agonist GW0742.

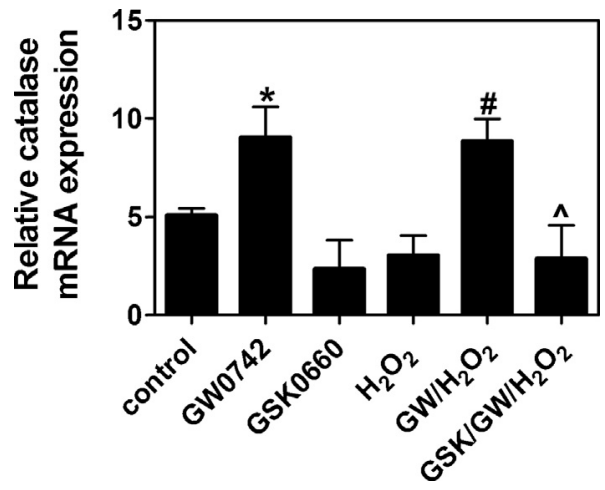

Fig. 5. Effect of pre-treatment of cardiac myocytes with PPAR $\beta / \delta$ agonist GW0742 on catalase mRNA expression. Cardiac myocytes were either left untreated or they were pretreated with PPAR $\beta / \delta$ GW0742 $(\mathrm{GW}, 50 \mathrm{nM})$ and/or PPAR $\beta / \delta$ antagonist GSK0660 (GSK, $0.5 \mu \mathrm{M})$. Then they were incubated in the absence or presence of $\mathrm{H}_{2} \mathrm{O}_{2}(0.1 \mathrm{mM})$ for $3 \mathrm{~h}$. Catalase mRNA levels were determined by real-time RT-PCR and were normalized to the mRNA levels of the housekeeping gene $\beta$-actin. Results are mean \pm SEM of 5 independent experiments. ${ }^{*} p<0.05$ compared with control, ${ }^{\#} p<0.05$ compared with treatment with $\mathrm{H}_{2} \mathrm{O}_{2}, p<0.05$ compared with cells treated with $\mathrm{H}_{2} \mathrm{O}_{2}$ and PPAR $\beta / \delta$ agonist GW0742.

As shown in Fig. 6, treatment of cardiac myocytes with PPAR $\beta / \delta$ agonist followed by $\mathrm{H}_{2} \mathrm{O}_{2}$ resulted in increased expression levels of anti-apoptotic Bcl-2 compared with cells that were exposed to $\mathrm{H}_{2} \mathrm{O}_{2}$ alone. In a similar fashion, the $\mathrm{H}_{2} \mathrm{O}_{2}$-induced increase in Bax was attenuated by the PPAR $\beta / \delta$ agonist. The effect of the agonist GW0742 on the expression of Bcl-2 family proteins was reversed in the presence of the antagonist GSK0660, indicating that this is a PPAR $\beta / \delta$-mediated effect. Taken together these results suggest that activation of PPAR $\beta / \delta$ leads to increased resistance to $\mathrm{H}_{2} \mathrm{O}_{2}-$ induced cardiac myocyte apoptosis through upregulation of $\mathrm{Bcl}-2$ and concomitant downregulation of Bax.

\subsection{PPAR $\beta / \delta$ activation leads to inhibition of MMP-2 and MMP-9 mRNA expression in cardiac myocytes exposed to $\mathrm{H}_{2} \mathrm{O}_{2}$}

Several studies have documented the role of matrix metalloproteinases (MMPs) in cardiac remodeling and the development of cardiac disease [29]. Furthermore, recent evidence implicates MMPs in the proteolytic regulation of several intracellular proteins in myocardial oxidative stress injury leading to cardiac dysfunction and cell death [30]. Thus, we determined the effect of PPAR $\beta / \delta$ activation on MMP-2 and MMP-9 mRNA expression. As expected, exposure of cardiac myocytes to $\mathrm{H}_{2} \mathrm{O}_{2}$ resulted in increased mRNA expression of both MMP-2 and MMP-9 (Fig. 7A and B). Pretreatment of cardiac myocytes with PPAR $\beta / \delta$ agonist GW0742 resulted in attenuation of MMP-2 and MMP-9 mRNA levels (Fig. 7A and $B)$. This effect was reversed by the addition of PPAR $\beta / \delta$ antagonist.

\section{Discussion}

In this study, we focus on the potential beneficial role of PPAR $\beta / \delta$ against oxidative stress induced dysfunction in cardiac myocytes. We provide evidence that PPAR $\beta / \delta$ activation by its specific agonist GW0742 protects cardiac myocytes from apoptosis via suppression of RONS generation and MMP gene expression.

The role of PPARs in the pathogenesis of various cardiovascular diseases has not been fully elucidated and remains a matter of controversy. Although PPAR $\beta / \delta$ is the less studied isoform, especially in the heart, there is mounting evidence supporting its cardioprotective role. PPAR $\beta / \delta$ is downregulated in rat heart after I/R [14] whereas conditional cardiac-specific deletion of PPAR $\beta / \delta$ results in increased cardiac lipid accumulation and cardiomyopathy [20]. Furthermore, PPAR $\beta / \delta$ agonists are cardioprotective in the setting of $I / R$ as manifested by a reduced infarct size and improved postischaemic recovery of contractile function in different animal models [31,32, Lazou et al. unpublished data]. In addition, activation of PPAR $\beta / \delta$ has been related to inhibition of hypertrophy and inflammation through the suppression of NF- $\kappa \mathrm{B}$ and inflammatory cytokines [33-35].

$\mathrm{H}_{2} \mathrm{O}_{2}$, as a physiologically relevant form of oxidative stress, induces cardiac myocyte apoptosis [24-26]. In line with a cardioprotective role of PPAR $\beta / \delta$, we demonstrate that pretreatment of cardiac myocytes with the PPAR $\beta / \delta$ selective agonist GW0742 increases cell viability and inhibits $\mathrm{H}_{2} \mathrm{O}_{2}$-induced apoptosis (Figs. 2 and 3) Furthermore, pretreatment with the selective 

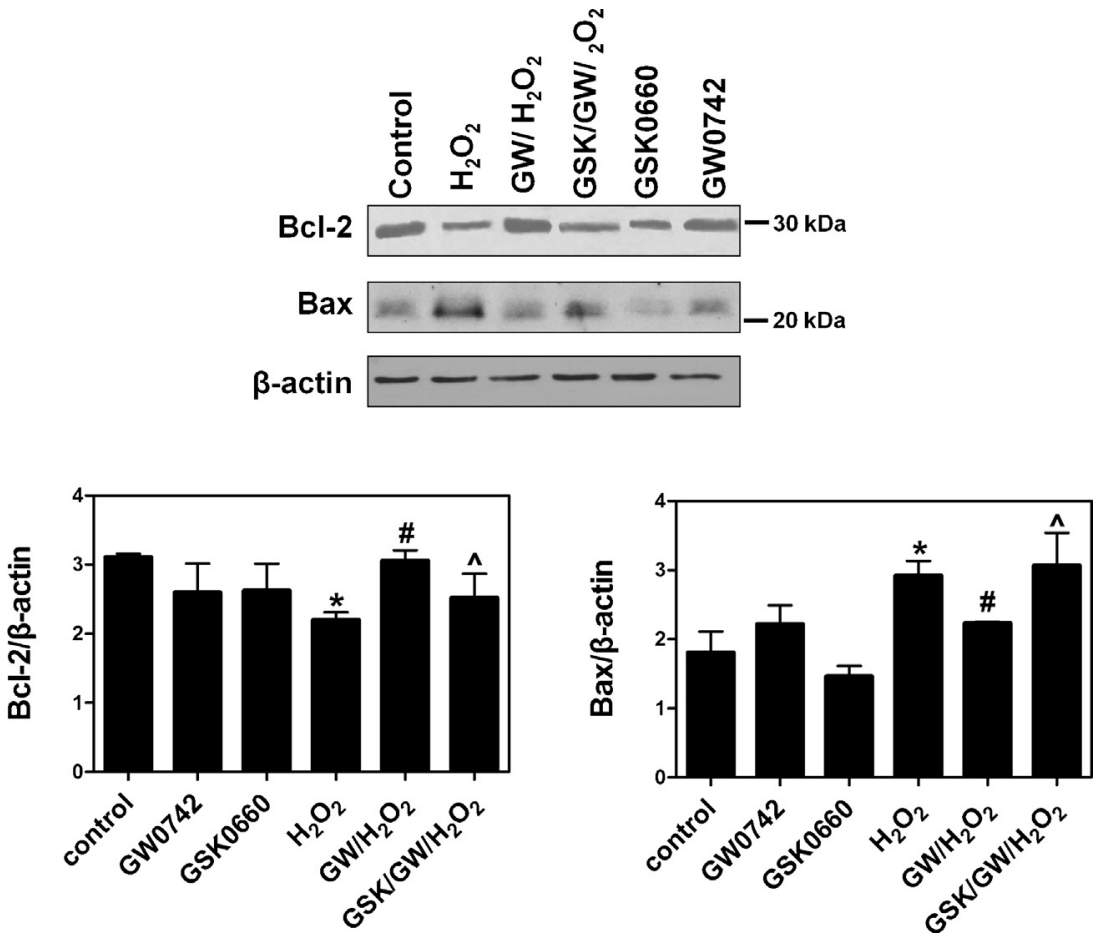

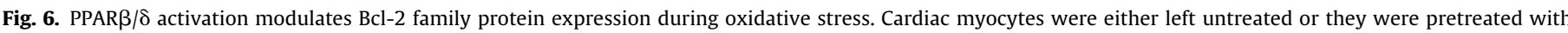

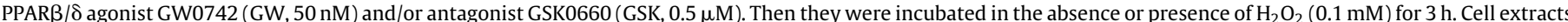

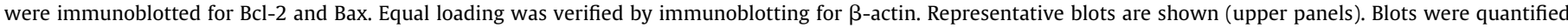

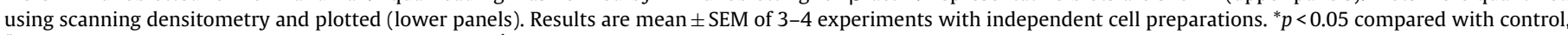
${ }^{\#} p<0.05$ compared with cells treated only with $\mathrm{H}_{2} \mathrm{O}_{2}, \hat{p} p<0.05$ compared with cells treated with $\mathrm{H}_{2} \mathrm{O}_{2}$ and PPAR $\beta / \delta$ agonist GW0742.

$\operatorname{PPAR} \beta / \delta$ antagonist GSK0660 abolishes the protection afforded by GW0742, and this finding implies that the observed beneficial effects of GW0742 are indeed secondary to the selective activation of the PPAR $\beta / \delta$ receptor. There are several potential mechanisms by which the PPAR $\beta / \delta$ agonist may exert its anti-apoptotic effect. Our results show that addition of the PPAR $\beta / \delta$ agonist in cardiac myocytes ameliorates oxidative stress as evidenced by the inhibition of RONS generation (Fig. 4). Many important endogenous anti-oxidants such as $\mathrm{Cu} / \mathrm{Zn}$-superoxide dismutase (SOD1), manganese superoxide dismutases (SOD2) and catalase contain functional PPAR response elements (PPREs) in their promoter and a role of PPAR $\beta / \delta$ in the transcriptional regulation of these enzymes has been previously reported $[21,28,36]$. Upregulation of the catalase gene was observed in the presence of PPAR $\beta / \delta$ agonist in cardiac myocytes (Fig. 5). Although catalase activity was not measured in this study, increased catalase gene expression may indicate an increased anti-oxidant capacity. PPAR $\beta / \delta$ has been suggested to inhibit ROS generation through the inhibition of NADPH oxidases in vascular smooth muscle cells exposed to angiotensin II [37]. However, as the $\mathrm{H}_{2} \mathrm{O}_{2}$-induced RONS generation in cardiac myocytes cannot be fully recovered in the presence of both PPAR $\beta / \delta$ agonist and antagonist (Fig. 4), we cannot exclude the possibility that
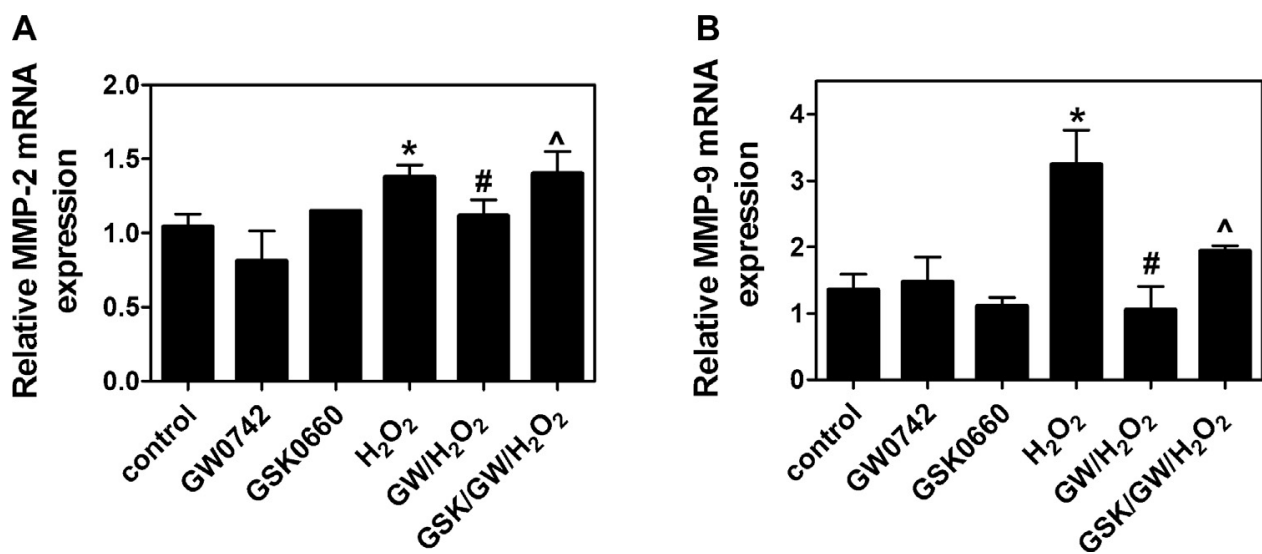

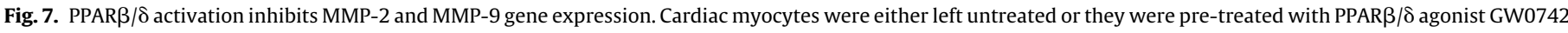

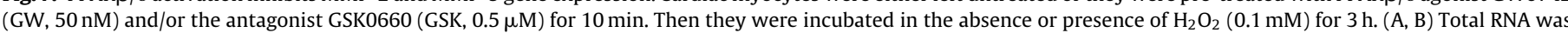

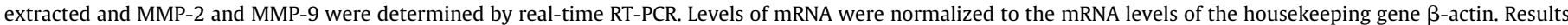

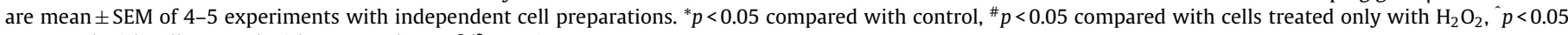
compared with cells treated with $\mathrm{H}_{2} \mathrm{O}_{2}$ and PPAR $\beta / \delta$ agonist GW0742. 
the agonist GW0742 has an additional anti-oxidant effect independent of PPAR $\beta / \delta$ activation. In fact, we have previously shown that PPAR $\beta / \delta$ agonist GW0742 can inhibit the phenylephrine-induced RONS generation in cardiac myocytes through a non-genomic redox mechanism [38].

Bcl-2 family proteins are key components of the apoptotic process in cardiac myocytes [5]. Bcl-2 proteins can be regulated either by transcription, heterodimerization or proteolytic cleavage, whereas their phosphorylation status plays important role in those events. Treatment with PPAR $\beta / \delta$ agonist GW0742 reversed the detrimental effect of $\mathrm{H}_{2} \mathrm{O}_{2}$ on $\mathrm{Bcl}-2$ expression while it led to a significant decrease of the proapoptotic Bax protein levels (Fig. 6). These results are consistent with previous studies demonstrating cardioprotection associated with modulation of cardiac levels of antiapoptotic (Bcl-2 and Bcl-xl) or proapoptotic (Bax and Bad) proteins $[17,31,39]$. The present data do not document a direct causal link between PPAR $\beta / \delta$ activation and modulation of Bcl-2 or Bax expression. It is possible that the observed $\mathrm{Bcl}-2$ upregulation in our experimental setting results from the PPAR $\beta / \delta$-induced amelioration of oxidative stress or PPAR $\beta / \delta$ crosstalk with other signaling pathways. Furthermore, we cannot exclude the possibility that besides Bcl-2 and Bax, other proteins acting in the mitochondrial-dependent apoptotic pathway are also affected by $\operatorname{PPAR} \beta / \delta$ activation and might contribute to the observed cardioprotective effects.

Increased RONS promote MMP activities. MMP activation is associated with degradation and remodeling of extracellular matrix under pathological conditions, thus leading to heart failure [40]. It is now becoming clear that, beyond their effects on matrix metabolism, MMPs (in particular MMP-2) are capable of modulating inflammatory pathways by processing cytokines, chemokines, and growth factors [41] as well as affecting many other relevant mediators involved in a variety of functions and pathogenic mechanisms leading to cardiac dysfunction $[30,42]$. In fact, MMP2 has been shown to be involved in the intracellular degradation of troponin I [43], myosin light chain 1 [44] and nuclear PARP $[45,46]$. Inhibition of MMP activity has been shown to protect the myocardium form oxidative/nitrosative stress-induced injury suggesting novel targets for cardiac failure management $[10,47]$. The data of this study clearly demonstrate that PPAR $\beta / \delta$ agonist GW0742 downregulates the $\mathrm{H}_{2} \mathrm{O}_{2}$-induced MMP-2 and MMP-9 gene overexpression (Fig. 7) in cardiac myocytes. Moreover this effect is reversed by administration of the PPAR $\beta / \delta$ antagonist GSK0660. It is not clear whether there is a direct link between PPAR activation and MMP inhibition. The inhibitory effect of PPARs on NF- $\kappa$ B is well documented [19], whereas there are reports demonstrating a role of NF- $\kappa B$ in the activation of MMPs $[48,49]$. Thus, the observed MMP dowregulation in cardiac myocytes (Fig. 7) may be the result of the anti-inflammatory action of PPAR $\beta / \delta$. In this context, it has been shown that a PPAR $\beta / \delta$ agonist markedly suppresses the IL-1 $\beta$-induced MMP-2 and MMP-9 expression in vascular smooth muscle cells [50]. This issue warrants further investigation. Furthermore, we cannot rule out the possibility that MMP suppression by the agonist GW0742 in our experimental model might be a secondary effect through the modulation of oxidative stress.

In conclusion, our results demonstrate that the PPAR $\beta / \delta$ agonist GW0742 inhibits cardiac myocyte injury by reducing oxidative stress and inhibiting MMP expression and apoptosis. Its protective effects are dependent on the activation of PPAR $\beta / \delta$ because they are abolished by pretreatment with the PPAR $\beta / \delta$ antagonist GSK0660. Although additional experiments are needed to clarify the role of PPAR $\beta / \delta$ in cardiac myocytes apoptosis, the results presented here suggest that the connection between PPAR signaling and MMP suppression might represent a new target for the management of oxidative stress-induced cardiac dysfunction.

\section{Acknowledgements}

The work has been co-financed by the European Union (European Social Fund) and Greek National Funds (GSRT-HUN57), and the Hungarian Scientific Research Fund: OTKA PD 106001. G.A holds a "János Bolyai Fellowship" from the Hungarian Academy of Sciences, P.J. holds a "Apáczai-Csere János Fellowship" from TÁMOP-4.2.4.A/2-11/1-2012-0001 (National Excellence Program). P.F. is a Szentágothai Fellow of the National Program of Excellence (TAMOP 4.2.4.A/2-11-1-2012-0001).

\section{References}

[1] C. Ceconi, A. Boraso, A. Cargnoni, R. Ferrari, Oxidative stress in cardiovascular disease: myth or fact? Arch. Biochem. Biophys. 420 (2) (2003) 217-221, http://dx.doi.org/10.1016/j.abb.2003.06.002.

[2] E. Takimoto, D.A. Kass, Role of oxidative stress in cardiac hypertrophy and remodeling, Hypertension 49 (2) (2007) 241-248, http://dx.doi.org/ 10.1161/01.HYP.0000254415.31362.a7.

[3] R.S. Whelan, V. Kaplinskiy, R.N. Kitsis, Cell death in the pathogenesis of heart disease: mechanisms and significance, Annu. Rev. Physiol. 72 (2010) 19-44, http://dx.doi.org/10.1146/annurev.physiol.010908.163111.

[4] A. Clerk, S.M. Cole, T.E. Cullingford, J.G. Harrison, M. Jormakka, et al., Regulation of cardiac myocyte cell death, Pharmacol. Ther. 97 (3) (2003) 223-261, http://dx.doi.org/10.1016/S0163-7258(02)00339-X.

[5] A.B. Gustafsson, R.A. Gottlieb, Bcl-2 family members and apoptosis, taken to heart, Am. J. Physiol. Cell Physiol. 292 (1) (2007) C45-C51, http://dx.doi.org/ 10.1152/ajpcell.00229.2006.

[6] S.N. Willis, J.M. Adams, Life in the balance: how BH3-only proteins induce apoptosis, Curr. Opin. Cell Biol. 17 (6) (2005) 617-625, http://dx.doi.org/ 10.1016/j.ceb.2005.10.001

[7] A. Page-McCaw, A.J. Ewald, Z. Werb, Matrix metalloproteinases and the regulation of tissue remodelling, Nat. Rev. Mol. Cell Biol. 8 (3) (2007) 221-233, http://dx.doi.org/10.1038/nrm2125.

[8] D.A. Siwik, W.S. Colucci, Regulation of matrix metalloproteinases by cytokines and reactive oxygen/nitrogen species in the myocardium, Heart Fail. Rev. 9 (1) (2004) 43-51.

[9] J. Shen, D. O’Brien, Y. Xu, Matrix metalloproteinase-2 contributes to tumor necrosis factor alpha induced apoptosis in cultured rat cardiac myocytes, Biochem. Biophys. Res. Commun. 347 (4) (2006) 1011-1020, http://dx.doi.org/ 10.1016/j.bbrc.2006.07.002.

[10] G. Dormán, S. Cseh, I. Hajdú, L. Barna, D. Kónya, et al., Matrix metalloproteinase inhibitors: a critical appraisal of design principles and proposed therapeutic utility, Drugs 70 (May (8)) (2010) 949-964, http://dx.doi.org/10.2165/ 11318390-000000000-00000.

[11] Q. Yang, Y. Li, Roles of PPARs on regulating myocardial energy and lipid homeostasis, J. Mol. Med. (Berl.) 85 (7) (2007) 697-706, http://dx.doi.org/ 10.1007/s00109-007-0170-9.

[12] G.D. Girnun, F.E. Domann, S.A. Moore, M.E. Robbins, Identification of a functional peroxisome proliferator-activated receptor response element in the rat catalase promoter, Mol. Endocrinol. 16 (12) (2002) 2793-2801, http://dx.doi. org/10.1210/me.2002-0020.

[13] Q. Ding, T. Jin, Z. Wang, Y. Chen, Catalase potentiates retinoic acid-induced THP-1 monocyte differentiation into macrophage through inhibition of peroxisome proliferator-activated receptor gamma, J. Leukoc. Biol. 81 (6) (2007) 1568-1576, http://dx.doi.org/10.1189/jlb.1106672.

[14] T. Ravingerova, A. Adameova, S. Carnicka, M. Nemcekova, T. Kelly, J. Matejikova, E. Barlaka, E.A. Lazou, et al., The role of PPAR in myocardial response to ischemia in normal and diseased heart, Gen. Physiol. Biophys. 30 (4) (2011) 329-341, http://dx.doi.org/10.4149/gpb_2011_04_329.

[15] C. Lotz, M. Lazariotto, A. Redel, T.M. Smul, J. Stumpner, et al., Activation of peroxisome-proliferator-activated receptors $\alpha$ and $\gamma$ mediates remote ischemic preconditioning against myocardial infarction in vivo, Exp. Biol. Med. 236 (1) (2011) 113-122, http://dx.doi.org/10.1258/ebm.2010.010210.

[16] T. Ravingerová, S. Carnická, M. Nemčeková, V. Ledvényiová, A. Adameová, T. Kelly, E. Barlaka, E. Galatou, V.K. Khandelwal, A. Lazou, PPAR-alpha activation as a preconditioning-like intervention in rats in vivo confers myocardial protection against acute ischaemia-reperfusion injury: involvement of PI3K-Akt, Can. J. Physiol. Pharmacol. 90 (8) (2012) 1135-1144, http://dx.doi.org/10.1139/y2012-052.

[17] E. Barlaka, V. Ledvényiová, E. Galatou, M. Ferko, S. Čarnická, et al., Delayed cardioprotective effects of WY-14643 are associated with inhibition of MMP2 and modulation of Bcl-2 family proteins through PPAR- $\alpha$ activation in rat hearts subjected to global ischaemia-reperfusion, Can. J. Physiol. Pharmacol. 91 (8) (2013) 608-616, http://dx.doi.org/10.1139/cjpp-2012-0412.

[18] I. Inoue, S. Goto, T. Matsunaga, T. Nakajima, T. Awata, et al., The ligands/activators for peroxisome proliferator-activated receptor alpha (PPARalpha) and PPARgamma increase $\mathrm{Cu}^{2+}, \mathrm{Zn}^{2+}$-superoxide dismutase and decrease p22phox message expressions in primary endothelial cells, Metabolism 50 (1) (2001) 3-11, http://dx.doi.org/10.1053/meta.2001.19415.

[19] P.J. Smeets, A. Planavila, G.J. van der Vusse, M. van Bilsen, Peroxisome proliferator-activated receptors and inflammation: take it to heart, Acta 
Physiol. (Oxf.) 191 (3) (2007) 171-188, http://dx.doi.org/10.1111/j.1748-1716. 2007.01752.x.

[20] L. Cheng, G. Ding, Q. Qin, Y. Huang, W. Lewis, et al., Cardiomyocyte-restricted peroxisome proliferator-activated receptor-delta deletion perturbs myocardial fatty acid oxidation and leads to cardiomyopathy, Nat. Med. 10 (11) (2004) 1245-1250, http://dx.doi.org/10.1038/nm1116.

[21] P. Wang, J. Liu, Y. Li, S. Wu, J. Luo, et al., Peroxisome proliferator-activated receptor delta\} is an essential transcriptional regulator for mitochondrial protection and biogenesis in adult heart, Circ. Res. 106 (5) (2010) 911-919, http://dx.doi.org/10.1161/CIRCRESAHA.109.206185.

[22] M.L. Sznaidman, C.D. Haffner, P.R. Maloney, A. Fivush, E. Chao, et al., Novel selective small molecule agonists for peroxisome proliferator-activated receptor delta (PPARdelta) - synthesis and biological activity, Bioorg. Med. Chem. Lett. 13 (9) (2003) 1517-1521, http://dx.doi.org/10.1016/S0960-894X(03)00207-5.

[23] B.G. Shearer, D.J. Steger, J.M. Way, T.B. Stanley, D.C. Lobe, et al., Identification and characterization of a selective peroxisome proliferator-activated receptor beta/delta (NR1C2) antagonist, Mol. Endocrinol. 22 (2) (2008) 523-529, http://dx.doi.org/10.1210/me.2007-0190.

[24] T. Markou, A.A. Dowling, T. Kelly, A. Lazou, Regulation of Bcl-2 phosphorylation in response to oxidative stress in cardiac myocytes, Free Radic. Res. 43 (9) (2009) 809-816, http://dx.doi.org/10.1080/10715760903071649.

[25] D. Cieslak, A. Lazou, Regulation of BAD protein by PKA, PKCdelta and phosphatases in adult rat cardiac myocytes subjected to oxidative stress, Mol. Cells 24 (2) (2007) 224-231.

[26] T. Markou, E. Barlaka, M. Bartucci, A. Lazou, Signal transduction pathways through cytoprotective, apoptotic and hypertrophic stimuli: a comparative study in adult cardiac myocytes, Cell Biochem. Funct. 29 (6) (2011) 442-451, http://dx.doi.org/10.1002/cbf.1770.

[27] M.A. O'Brien, R.A. Moravec, T.L. Riss, Poly (ADP-ribose) polymerase cleavage monitored in situ in apoptotic cells, Biotechniques 30 (4) (2001) 886-891.

[28] M. Pesant, S. Sueur, P. Dutartre, M. Tallandier, P.A. Grimaldi, et al., Peroxisome proliferator-activated receptor delta (PPARdelta) activation protects $\mathrm{H} 9 \mathrm{c} 2 \mathrm{car}$ diomyoblasts from oxidative stress-induced apoptosis, Cardiovasc. Res. 69 (2) (2006) 440-449, http://dx.doi.org/10.1016/j.cardiores.2005.10.019.

[29] P. Liu, M. Sun, S. Sader, Matrix metalloproteinases in cardiovascular disease, Can. J. Cardiol. 22 (Suppl. B) (2006) 25B-30B.

[30] A.L. Jacob-Ferreira, R. Schulz, Activation of intracellular matrix metalloproteinase-2 by reactive oxygen-nitrogen species: consequences and therapeutic strategies in the heart, Arch. Biochem. Biophys. 540 (1-2) (2013) 82-93, http://dx.doi.org/10.1016/j.abb.2013.09.019.

[31] T.L. Yue, S.S. Nerurkar, W. Bao, B.M. Jucker, L. Sarov-Blat, et al., In vivo activation of peroxisome proliferator-activated receptor-delta protects the heart from ischemia/reperfusion injury in Zucker fatty rats, J. Pharmacol. Exp. Ther. 325 (2) (2008) 466-474, http://dx.doi.org/10.1124/jpet.107.135327.

[32] A. Kapoor, M. Collino, S. Castiglia, R. Fantozzi, C. Thiemermann, Activation of peroxisome proliferator-activated receptor-beta/delta attenuates myocardial ischemia/reperfusion injury in the rat, Shock 34 (2) (2010) 117-124, http://dx.doi.org/10.1097/SHK.0b013e3181cd86d6.

[33] F. Liang, F. Wang, S. Zhang, D.G. Gardner, Peroxisome proliferator activated receptor (PPAR)alpha agonists inhibit hypertrophy of neonatal rat cardiac myocytes, Endocrinology 144 (9) (2003) 4187-4194, http://dx.doi.org/10. 1210/en.2002-0217.

[34] A. Planavila, J.C. Laguna, M. Vázquez-Carrera, Atorvastatin improves peroxisome proliferator-activated receptor signaling in cardiac hypertrophy by preventing nuclear factor-kappa B activation, Biochim. Biophys. Acta 1687 (1-3) (2005) 76-83, http://dx.doi.org/10.1016/j.bbalip.2004.11.004.

[35] L. Sheng, P. Ye, Y.X. Liu, C.G. Han, Z.Y.Zhang, Peroxisome proliferator-activated receptor beta/delta activation improves angiotensin II-induced cardiac hypertrophy in vitro, Clin. Exp. Hypertens. 30 (2)(2008) 109-119, http://dx.doi. org/10.1080/10641960801945840.

[36] J. Liu, P. Wang, J. Luo, Y. Huang, L. He, et al., Peroxisome proliferator-activated receptor $\beta / \delta$ activation in adult hearts facilitates mitochondrial function and cardiac performance under pressure-overload condition, Hypertension 57 (2) (2011) 223-230, http://dx.doi.org/10.1161/HYPERTENSIONAHA.110.164590.

[37] H. Lee, S.A. Ham, M.Y. Kim, J.H. Kim, K.S. Paek, et al., Activation of PPAR counteracts angiotensin II-induced ROS generation by inhibiting rac1 translocation in vascular smooth muscle cells, Free Radic. Res. 46 (7) (2012) 912-919, http://dx.doi.org/10.3109/10715762.2012.687448.

[38] E. Galatou, T. Kelly, A. Lazou, The PPAR $\beta / \delta$ agonist GW0742 modulates signaling pathways associated with cardiac myocyte growth via a nongenomic redox mechanism, Mol. Cell. Biochem. 395 (1-2) (2014) 145-154, http://dx.doi.org/10.1007/s11010-014-2120-5.

[39] K. Imahashi, M.D. Schneider, C. Steenbergen, E. Murphy, Transgenic expression of Bcl-2 modulates energy metabolism, prevents cytosolic acidification during ischemia, and reduces ischemia/reperfusion injury, Circ. Res. 95 (7) (2004) 734-741, http://dx.doi.org/10.1161/01.RES.0000143898.67182.4c.

[40] J.T. Peterson, The importance of estimating the therapeutic index in the development of matrix metalloproteinase inhibitors, Cardiovasc. Res. 69 (3) (2006) 677-687, http://dx.doi.org/10.1016/j.cardiores.2005.11.032.

[41] M. Dobaczewski, C. Gonzalez-Quesada, N.G. Frangogiannis, The extracellular matrix as a modulator of the inflammatory and reparative response following myocardial infarction, J. Mol. Cell. Cardiol. 48 (3) (2010) 504-511, http://dx.doi.org/10.1016/j.yjmcc.2009.07.015.

[42] R. Schulz, Intracellular targets of matrix metalloproteinase-2 in cardiac disease: rationale and therapeutic approaches, Annu. Rev. Pharmacol. Toxicol. 47 (2007) 211-242, http://dx.doi.org/10.1146/annurev.pharmtox.47.120505.105230.

[43] W. Wang, C.J. Schulze, W.L. Suarez-Pinzon, J.R. Dyck, G. Sawicki, et al., Intracellular action of matrix metalloproteinase-2 accounts for acute myocardial ischemia and reperfusion injury, Circulation 106 (12) (2002) 1543-1549, http://dx.doi.org/10.1161/01.CIR.0000028818.33488.7B.

[44] G. Sawicki, H. Leon, J. Sawicka, M. Sariahmetoglu, C.J. Schulze, et al., Degradation of myosin light chain in isolated rat hearts subjected to ischemia-reperfusion injury: a new intracellular target for matrix metalloproteinase-2, Circulation 112 (4) (2005) 544-552, http://dx.doi.org/10.1161/CIRCULATIONAHA 104.531616.

[45] J.A. Kwan, C.J. Schulze, W. Wang, H. Leon, M. Sariahmetoglu, et al., Matrix metalloproteinase-2 (MMP-2) is present in the nucleus of cardiac myocytes and is capable of cleaving poly (ADP-ribose) polymerase (PARP) in vitro, FASEB J. 18 (6) (2004) 690-692, http://dx.doi.org/10.1096/fj.02-1202fje.

[46] A. DeCoux, M.L. Lindsey, F. Villarreal, R.A. Garcia, R. Schulz, Myocardial matrix metalloproteinase-2: inside out and upside down, J. Mol. Cell. Cardiol. 77 (2014) 64-72, http://dx.doi.org/10.1016/j.yjmcc.2014.09.016.

[47] C.Q. Gao, G. Sawicki, W.L. Suarez-Pinzon, T. Csont, M. Wozniak, et al., Matrix metalloproteinase-2 mediates cytokine-induced myocardial contractile dysfunction, Cardiovasc. Res. 57 (2) (2003) 426-433, http://dx.doi.org/10.1016/ S0008-6363(02)00719-8.

[48] S. Philip, A. Bulbule, G.C. Kundu, Matrix metalloproteinase-2: mechanism and regulation of NF-kappaB-mediated activation and its role in cell motility and ECM-invasion, Glycoconj. J. 21 (8-9) (2004) 429-441.

[49] C.S. Lee, Y.W. Kwon, H.M. Yang, S.H. Kim, T.Y. Kim, et al., New mechanism of rosiglitazone to reduce neointimal hyperplasia: activation of glycogen synthase kinase-3beta followed by inhibition of MMP-9, Arterioscler. Thromb. Vasc. Biol. 29 (4) (2009) 472-479, http://dx.doi.org/10.1161/ATVBAHA.108.176230.

[50] H.J. Kim, M.Y. Kim, J.S. Hwang, H.J. Kim, J.H. Lee, et al., PPARdelta inhibits IL-1beta-stimulated proliferation and migration of vascular smooth muscle cells via up-regulation of IL-1Ra, Cell. Mol. Life Sci. 67 (12) (2010) 2119-2130, http://dx.doi.org/10.1007/s00018-010-0328-4. 